\title{
THE IMPACT OF THREE BACTERIA ISOLATED FROM CONTAMINATED PLANT CULTURES ON IN VITRO MULTIPLICATION AND ROOTING OF MICROSHOOTS OF FOUR ORNAMENTAL PLANTS
}

\section{Research note}

\author{
Marta ZAWADZKA ${ }^{1}$, Paweł TRZCIŃSKI ${ }^{2}$, Katarzyna NOWAK ${ }^{2}$, Teresa ORLIKOWSKA*2 \\ ${ }^{1}$ Actual address: 87-800 Włocławek, Chmielna 32/15, Poland \\ ${ }^{2}$ Research Institute of Horticulture
}

Konstytucji 3 Maja 1/3, 96-100 Skierniewice, Poland

Received: October 8, 2013; Accepted: December 8, 2013

\begin{abstract}
The strains of bacteria Paenibacillus glucanolyticus, Curtobacterium pusillum and Methylobacterium extorquens were isolated as non-deleterious contaminations from hosta or raspberry tissue cultures. Microshoots of chrysanthemum, gerbera, hosta and rose were inoculated with these bacteria and their influence on shoot multiplication and rooting was evaluated. None of the investigated bacteria caused symptoms of hypersensitivity or vitropathy on the shoot explants at rooting and shoots multiplication. C. pusillum stimulated axillary shoot formation in all studied plant genotypes. Length and number of rose roots and their length were higher but number of roots and their length in chrysanthemum were lower in inoculated than in controls. The number and the length of shoots and roots in gerbera and hosta and the number of shoots in chrysanthemum inoculated with $M$. extorquens were higher but shoot length of chrysanthemum and rose, and root length of rose were lower as compared with controls. P. glucanolyticus influenced higher number and length of chrysanthemum shoots and root length of chrysanthemum and gerbera than noninoculated control but the number of gerbera and hosta roots was lower and root length of rose was as low as $0.2 \mathrm{~cm}$. All assessed bacteria were able to assimilate atmospheric nitrogen and $M$. extorquens and $P$. glucanolyticus were able to produce IAA.
\end{abstract}

Key words: beneficial bacteria, contamination, inoculation, rooting, shoot multiplication

\section{INTRODUCTION}

According to contemporary knowledge, it is difficult to imagine plant life without any bacteria (Holland \& Polacco 1994; Beattie 2006; Ryan et al. 2008). Bacteria populate surfaces of leaves, stems, fruits and roots (epiphytes), and the interior of the plant body, where they inhabit the vascular bundles, intercellular spaces and cell insides (endophytes) Some of them can be observed in an electron microscope as stable endosymbionts belonging to different bacterial groups (Almeida et al. 2009). Only strains of about 100 species of bacteria have been described as plant pathogens. Other bacteria species do not have a detrimental impact on plants and some were defined as beneficial for plants they colonize. Beneficial effects in stimulating growth and biomass increase resulted from the facilitation of nutrients absorption and production and provision of a variety of plant secondary metabolites, such as plant growth regulators (Ortiz-Castro et al. 2009), chitynolytic enzymes protecting against pathogenic organisms (Compant et al. 2005) and osmoprotectants that enable the overcoming of abiotic stresses (Sziderics et al. 2007). Endophytic and epiphytic bacteria take part in the expression of functional traits of plants (Friesen et al. 2011). The level of the beneficial impact of bacteria on plants depends on 
the bacterial traits, type of bacterial interactions with plant genotypes and biotic and abiotic factors that influence the interactions (Beattie 2006; Hardoim et al. 2008).

In vitro cultures are usually not microorganism free, as microorganisms can survive the surface decontamination within a plant body. Bacteria may appear soon after the initiation of cultures but often only after several passages (Cassels 1997, 2011).

Our survey of contaminated in vitro plant cultures obtained from different laboratories yielded 104 isolates of bacteria. Based on 16S rDNA sequencing and BIOLOG tests, they were assigned to 29 taxa (data not published). Some bacteria, although they often multiplied abundantly during the time of passage, which was visible as bacterial growth around microshoots or leakages into the medium, did not have a clear negative effect on the host explants. Using three bacterial strains that seemed to have a beneficial influence on contaminated cultures, the experiments were conducted to answer the question of whether they can modify the multiplication and rooting of microshoots of chrysanthemum, gerbera, hosta and rose.

\section{MATERIAL AND METHODS}

The chosen isolates were classified to the genus by sequencing nucleotides of $16 \mathrm{~S}$ rDNA obtained using $\mathrm{rd} 1 / \mathrm{fd} 1$ primers (Weisburg et al. 1991) and then to the species using BIOLOG tests, as Curtobacterium pusillum (N), Methylobacterium extorquens (67) and Paenibacillus glucanolyticus (I). The first two were isolated from raspberry shoot cultures and the third from hosta shoot cultures. The ability of strains to produce auxins (according to Pilet \& Chollet, after Glickmann \& Dessaux 1995), to fix atmospheric nitrogen (according to Ribeiro \& Cardozo 2012) and to dissolve inorganic phosphate (according to Panhwar et al. 2009) was assessed. As a control, strain Burkholderia phytofirmans PsJNTM (kindly gifted for research by Prof. Angela Sessitsch from the Austrian Institute of Technology) was used.

Experiments included microshoots of Chrysanthemum $\times$ grandiflorum (Ramat.) Kitam 'Ludo', Hosta Tratt. 'Paradigm', Gerbera jamesonii Bolus ex Hook 'Kormoran' and Rosa L. 'White Gem'. The shoots for experiment were harvested from the stock cultures "free of cultivable bacteria". These stocks were founded from microshoots indexed in two subsequent subcultures for the bacterial contamination by placing fragments of the lowest parts of shoots on two bacteriological media: Nutrient Agar (NA) and 523 medium (Viss et al. 1991). The shoots, from which bacteria did not grow, were considered as free of cultivable bacteria and micropropagated for the purpose of the experiment. The gerbera, hosta and rose were propagated by axillary shoots and chrysanthemum by single shoot elongation from nodal segments. Media used contained macro- and microelements according to Murashige and Skoog (1962), $100 \mathrm{mg} \cdot \mathrm{l}^{-1}$ of inositol, WPM (woody plant medium) (Lloyd \& McCown 1981) vitamins, $30 \mathrm{~g} \cdot 1^{-1}$ of sucrose and $6 \mathrm{~g} \cdot \mathrm{l}^{-1}$ of agar Plant (Duchefa) for gerbera, rose and chrysanthemum or $3 \mathrm{~g} \cdot \mathrm{l}^{-1}$ of Gelrite (Duchefa) for hosta. The medium for chrysanthemum contained $0.1 \mathrm{mg} \cdot \mathrm{l}^{-1}$ kinetin (KIN) and $2 \mathrm{mg} \cdot \mathrm{l}^{-1}$ gibberellic acid $\left(\mathrm{GA}_{3}\right)$, medium for hosta $5 \mathrm{mg} \cdot \mathrm{l}^{-1}$ 6-benzylaminopurine (BAP) and $0.1 \mathrm{mg} \cdot \mathrm{l}^{-1}$ 1-naphthalene acetic acid (NAA); for gerbera $2 \mathrm{mg} \cdot \mathrm{l}^{-1}$ $\mathrm{KIN}$ and $0.1 \mathrm{mg} \cdot \mathrm{l}^{-1}$ indole-3-acetic acid (IAA), and for rose $2 \mathrm{mg} \mathrm{l}^{-1} \mathrm{BAP}, 1 \mathrm{mg} \cdot 1^{-1} \mathrm{GA}_{3}$ and $0.1 \mathrm{mg} \cdot 1^{-1}$ indole-3-butyric acid (IBA). The $\mathrm{pH}$ of the media was adjusted to 5.7 before autoclaving. The temperature in the growth room was $23 \pm 2{ }^{\circ} \mathrm{C}$. An illumination of $16 \mathrm{~h}$ was provided by $40 \mathrm{~W}$ fluorescent lamps, and the intensity of irradiation was between 40 and $50 \mu \mathrm{mol} \cdot \mathrm{m}^{-2} \cdot \mathrm{sec}^{-1}$. Culture media were sterilized in an autoclave for $17 \mathrm{~min}$ at $121^{\circ} \mathrm{C}$ and pressure of $0.1 \mathrm{Mpa}$. The shoot explants were grown in glass jars of $350 \mathrm{ml}$ in volume, containing $35 \mathrm{ml}$ of a medium. There were five shoots in a jar and six jars per treatment.

In the initial experiment, different methods of microshoots inoculation with bacteria (bacterization) were compared. The most effective one was used in the experiment described here. The excised shoots were transferred to jars containing perlite saturated with liquid rooting medium and $100 \mu 1$ of $24 \mathrm{~h}$ bacterium inoculum of strains Curtobacterium and Paenibacillus and $48 \mathrm{~h}$ of Methylobacterium strain was added immediately in the centre of a jar of each plant species. Rooting media contained salts 
of MS ( $1 / 2$ MS for rose), WPM vitamins, inositol $100 \mathrm{mg} \cdot \mathrm{l}^{-1}, 30 \mathrm{~g} \cdot \mathrm{l}^{-1}$ sucrose with the addition of auxin (for chrysanthemum $0.5 \mathrm{mg} \cdot \mathrm{l}^{-1} \mathrm{IAA}$; for hosta $0.1 \mathrm{mg} \cdot \mathrm{l}^{-1} \mathrm{NAA}$, for gerbera $5 \mathrm{mg} \cdot \mathrm{l}^{-1} \mathrm{IAA}$, and for rose $1 \mathrm{mg} \cdot \mathrm{l}^{-1}$ IBA). For the initial 7 days, the cultures were incubated in the dark and then in the light at the photoperiod of $16 / 8$ and intensity of about $50 \mu \mathrm{mol} \cdot \mathrm{m}^{-2} \cdot \mathrm{s}^{-1}$.

After 4 weeks, the rooting was assessed by recording the length and the number of roots. Then, the lower parts of the shoots with roots were cut off and placed on the above-mentioned bacteriological media- NA and 523 for checking the presence of bacteria. The shoot tips were transferred to the shoot multiplication media to determine the effect of bacteria on the ability to form axillary shoots. The composition of the multiplication media was the same as above, with the exception that shoot tips of chrysanthemum were cultured on the medium with the kinetin content increased to $0.5 \mathrm{mg} \cdot \mathrm{l}^{-1}$. During multiplication, the shoot cultures were visually inspected for the bacterial presence and symptomatic bacterial leakages from the shoot proximity observed in the medium were streaked on the two above-mentioned bacterial media to check the presence and morphological identity of bacteria.

The results of shoot multiplication were assessed after 4 weeks, when the number and length of axillary shoots were recorded.
The microshoots from the above-mentioned step were used for the second experiment on rooting. The media were similar as in the first experiment, but solidified with agar. Rooting was assessed after 5 weeks, when the number and length of roots, as well as length of shoots and number of leaves, were scored. In this trial, only bacteria/plant combinations, which were beneficial for rooting in the first experiment, were studied.

The experiments were arranged as 1-factorial (bacteria inoculation), completely randomized with 30 microshoots in combination. The analysis of variance (ANOVA) was performed for the number of axillary shoots, number of roots, length of shoots and roots, and number of leaves according to the Freeman-Tukey's function. The significance of differences between means was tested using the Duncan's Multiple Range Tests at $p=0.05$.

The results are presented in chronological order.

\section{RESULTS}

\section{Characteristics of bacteria}

None of the assessed bacteria was able to solubilize phosphates. All were able to assimilate atmospheric nitrogen. Two bacteria $-M$. extorquens (67) and $P$. glucanolyticus (I) - were able to synthesize IAA. $P$. glucanolyticus had a high potential in IAA production, comparable to $B$. phytofirmas, whereas $M$. extorquens produced twice less IAA than the two above-mentioned strains (Table 1).

Table 1. Characteristics of strains used for bacterization and Burkholderia phytofirmans PsJNTM

\begin{tabular}{|c|c|c|c|c|c|c|}
\hline \multirow[t]{2}{*}{ Strain } & \multirow{2}{*}{$\begin{array}{c}16 \mathrm{~S} \text { rDNA } \\
\text { identification }\end{array}$} & \multirow{2}{*}{$\begin{array}{c}\text { BioLog } \\
\text { identification }\end{array}$} & \multicolumn{2}{|c|}{$\begin{array}{l}\text { Auxin production } \\
\text { in } \mu \mathrm{g} \cdot \mathrm{ml}^{-1}\end{array}$} & \multirow{2}{*}{$\begin{array}{l}\text { Air nitro- } \\
\text { gen assimi- } \\
\text { lation }\end{array}$} & \multirow{2}{*}{$\begin{array}{c}\text { Phosphate } \\
\text { solubiliza- } \\
\text { tion }\end{array}$} \\
\hline & & & after $24 \mathrm{~h}$ & after $48 \mathrm{~h}$ & & \\
\hline $\mathrm{N}$ & Curtobacterium spp. & $\begin{array}{l}\text { Curtobacterium pu- } \\
\text { sillum }\end{array}$ & - & - & + & - \\
\hline 67 & Methylobacterium spp. & $\begin{array}{l}\text { Methylobacterium ex- } \\
\text { torquens }\end{array}$ & 0.181 & 0.476 & + & - \\
\hline I & Bacillus spp. & $\begin{array}{l}\text { Paenibacillus glu- } \\
\text { canolyticus }\end{array}$ & 0.643 & 0.900 & + & - \\
\hline PsJNTM & $\begin{array}{l}\text { Burkholderia phytofir- } \\
\text { mans }\end{array}$ & Not tested & 0.318 & 0.919 & + & - \\
\hline
\end{tabular}




\section{Indexing of bacteria in explants}

From all the bottom parts of the shoots rooted in the medium inoculated with bacteria, bacteria of the morphology similar to the ones used for bacterization were re-isolated on NA and 523 media. The shoots were transplanted into the shoot multiplication media solidified with agar and examined visually for the presence of bacteria (clouding below or transparent halo around explant). Symptoms of bacterial presence appeared on nearly all explants within the first 1-3 weeks after transferring of the microshoots. $M$. extorquens strain growth turned pink after 2-3 weeks. Only explants in which the presence of bacteria was confirmed were accounted to as experimental objects. None of the investigated bacteria caused any hypersensitivity reaction or other vitropathy symptoms on the shoot explants during the rooting or the shoot multiplication.

\section{Rooting of shoots directly after inoculation with bacteria}

In this trial $C$. pusillum stimulated rooting - the number and the length of roots of rose (4.3 versus 2.3 roots, 1.6 versus $1.3 \mathrm{~cm}$ ), and the root length of hosta $(3.2$ versus $1.0 \mathrm{~cm})$ in comparison to the noninoculated control. This bacterium decreased the number of roots by 1.7 and their length by $1.0 \mathrm{~cm}$ in chrysanthemum as compared to the uninoculated control. It had no influence on the number of the roots of gerbera and hosta (Table 2). M. extorquens strain increased twice the number and the root length of gerbera in comparison with non-inoculated control. The rooting of hosta was influenced even stronger as number of roots was 4.8 versus 1.8 and length 5.9 versus 1.0 in comparison with control (Table 2). P. glucanolyticus stimulated only the root length of chrysanthemum and gerbera but diminished the number of roots of hosta and reduced root length of rose up to $0.2 \mathrm{~cm}$ (Table 2).
Multiplication of shoots derived from shoots inoculated with bacteria (4 weeks after inoculation)

C. pusillum strain stimulated the number of axillary shoots of gerbera and hosta and doubled the shoot number of rose in comparison to uninoculated control. It also slightly stimulated shoot elongation in rose. M. extorquens had stimulatory effect on the number of shoots of chrysanthemum, gerbera and hosta and the length of shoots of gerbera and hosta. It doubled the shoot number of gerbera and hosta in comparison with the control. It also diminished the shoot length of chrysanthemum and rose. P. glucanolyticus influenced only shoot multiplication in chrysanthemum and caused decrease in the shoot length of hosta (Table 3).

\section{Rooting of shoots derived from the multiplica- tion passage ( 9 weeks after inoculation with bac- teria)}

In the second rooting trial, only combinations, where a positive interaction between host and bacteria were observed, were studied. A positive influence on rooting was confirmed for all bacteria/host combination with the exception of $M$. extorquens/Hosta where bacteria decreased root length (Table 4). Rooted shoots of chrysanthemum derived from cultures inoculated 9 weeks before experiment were higher (6.1 versus $4.6 \mathrm{~cm}$ ) with more leaves (18.4 versus 10.0) and longer roots (11.4 versus $7.5 \mathrm{~cm}$ ) in comparison with non-inoculated control. Gerbera shoots inoculated with $M$. extorquens had more leaves (8.8 versus 7.1$)$ and longer roots (5.9 versus $3.8 \mathrm{~cm}$ ) in comparison with the control. Only in combination C. pusillum/Rose all parameters of the rooted shoots were higher than in non-inoculated control (Table 4). Shoots were 35\% heigher and leaves $38 \%$ more numerous, $93 \%$ more roots was formed and they were $23 \%$ longer. 
Table 2. Rooting of microshoots directly after inoculation with bacteria. Shaded cells show means, which differ negatively from non-inoculated control. Bolded means are significantly different from control in a positive sense

\begin{tabular}{|c|c|c|c|c|c|c|c|c|}
\hline \multirow[b]{2}{*}{ Plant genotype } & \multicolumn{2}{|c|}{ Control } & \multicolumn{2}{|c|}{$\begin{array}{c}\text { Curtobacterium } \\
\text { pusillum }(\mathrm{N})\end{array}$} & \multicolumn{2}{|c|}{$\begin{array}{c}\text { Methylobacterium } \\
\text { extorquens }(67)\end{array}$} & \multicolumn{2}{|c|}{$\begin{array}{c}\text { Paenibacillus glu- } \\
\text { canolyticus (I) }\end{array}$} \\
\hline & $\begin{array}{l}\text { Root } \\
\text { No. }\end{array}$ & $\begin{array}{l}\text { Root } \\
\text { length } \\
(\mathrm{cm})\end{array}$ & $\begin{array}{l}\text { Root } \\
\text { No. }\end{array}$ & $\begin{array}{l}\text { Root } \\
\text { length } \\
(\mathrm{cm})\end{array}$ & $\begin{array}{l}\text { Root } \\
\text { No. }\end{array}$ & $\begin{array}{l}\text { Root } \\
\text { length } \\
(\mathrm{cm})\end{array}$ & $\begin{array}{l}\text { Root } \\
\text { No. }\end{array}$ & $\begin{array}{l}\text { Root } \\
\text { length } \\
(\mathrm{cm})\end{array}$ \\
\hline $\begin{array}{l}\text { Chrysanthemum } \times \text { grandi- } \\
\text { florum 'Ludo' }\end{array}$ & $4.9 b$ & $1.7 \mathrm{~b}$ & $3.2 \mathrm{a}$ & $0.7 \mathrm{a}$ & $4.8 b$ & $1.9 \mathrm{~b}$ & $5.2 \mathrm{~b}$ & $3.5 \mathrm{c}$ \\
\hline $\begin{array}{l}\text { Gerbera jamesonii 'Kormo- } \\
\text { ran' }\end{array}$ & $1.8 \mathrm{~b}$ & $0.6 \mathrm{a}$ & $2.4 \mathrm{~b}$ & $0.5 \mathrm{a}$ & $3.6 \mathrm{c}$ & $1.2 \mathrm{c}$ & $1.0 \mathrm{a}$ & $0.8 b$ \\
\hline Hosta 'Paradigm' & $1.8 \mathrm{~b}$ & $1.0 \mathrm{a}$ & $2.4 \mathrm{~b}$ & $3.2 \mathrm{~b}$ & $4.8 \mathrm{c}$ & $5.9 \mathrm{c}$ & $1.0 \mathrm{a}$ & $1.1 \mathrm{a}$ \\
\hline Rose 'White Gem' & $2.3 \mathrm{a}$ & $1.3 \mathrm{~b}$ & $4.3 b$ & $1.6 \mathrm{c}$ & $2.2 \mathrm{a}$ & $0.9 \mathrm{a}$ & $2.5 \mathrm{a}$ & $0.2 \mathrm{a}$ \\
\hline
\end{tabular}

Table 3. Multiplication of microshoots derived from microshoots inoculated before 4 weeks. Shaded cells show means, which differ negatively from non-inoculated control. Bolded means are significantly different from control in a positive sense

\begin{tabular}{lcccccccc}
\hline \multirow{2}{*}{ Plant genotype } & \multicolumn{2}{c}{ Control } & \multicolumn{2}{c}{$\begin{array}{c}\text { Curtobacterium } \\
\text { pusillum }(\mathrm{N})\end{array}$} & \multicolumn{2}{c}{$\begin{array}{c}\text { Methylobacterium } \\
\text { extorquens }(67)\end{array}$} & $\begin{array}{c}\text { Paenibacillus glu- } \\
\text { canolyticus }(\mathrm{I})\end{array}$ \\
\cline { 2 - 9 } & $\begin{array}{c}\text { Shoot } \\
\text { No. }\end{array}$ & $\begin{array}{c}\text { Shoot } \\
\text { length } \\
(\mathrm{cm})\end{array}$ & $\begin{array}{c}\text { Shoot } \\
\text { No. }\end{array}$ & $\begin{array}{c}\text { Shoot } \\
\text { length } \\
(\mathrm{cm})\end{array}$ & $\begin{array}{c}\text { Shoot } \\
\text { No. }\end{array}$ & $\begin{array}{c}\text { Shoot } \\
\text { length } \\
(\mathrm{cm})\end{array}$ & $\begin{array}{c}\text { Shoot } \\
\text { No. }\end{array}$ & $\begin{array}{c}\text { Shoot } \\
\text { length } \\
(\mathrm{cm})\end{array}$ \\
\hline $\begin{array}{l}\text { Chrysanthemum } \times \text { grandi- } \\
\text { florum 'Ludo' }\end{array}$ & $2.0 \mathrm{a}$ & $5.8 \mathrm{~b}$ & $2.2 \mathrm{a}$ & $5.6 \mathrm{~b}$ & $\mathbf{2 . 5 b}$ & $5.3 \mathrm{a}$ & $\mathbf{3 . 2 c}$ & $\mathbf{6 . 5 c}$ \\
\hline $\begin{array}{l}\text { Gerbera jamesonii 'Kormo- } \\
\text { ran' }\end{array}$ & $1.9 \mathrm{a}$ & $2.4 \mathrm{a}$ & $\mathbf{2 . 5 b}$ & $2.4 \mathrm{a}$ & $\mathbf{3 . 8 c}$ & $\mathbf{4 . 1 b}$ & $2.2 \mathrm{ab}$ & $2.2 \mathrm{a}$ \\
\hline $\begin{array}{l}\text { Hosta 'Paradigm' } \\
\text { Rose 'White Gem' }\end{array}$ & $1.9 \mathrm{a}$ & $1.8 \mathrm{~b}$ & $\mathbf{2 . 7 b}$ & $1.5 \mathrm{~b}$ & $\mathbf{3 . 9 c}$ & $\mathbf{2 . 7 c}$ & $2.0 \mathrm{a}$ & $1.0 \mathrm{a}$ \\
\hline
\end{tabular}

Table 4. Rooting of second vegetative generation microshoots derived from cultures inoculated before 9 weeks. Shaded cells show means, which differ negatively from non-inoculated control. Bolded means are significantly different from control in a positive sense

\begin{tabular}{|c|c|c|c|c|c|c|c|c|}
\hline \multirow{3}{*}{ Plant genotype/bacteria } & \multicolumn{2}{|c|}{$\begin{array}{l}\text { Shoot height } \\
(\mathrm{cm})\end{array}$} & \multicolumn{2}{|c|}{ Leaves No. } & \multicolumn{2}{|c|}{ Root No. } & \multicolumn{2}{|c|}{$\begin{array}{l}\text { Root length } \\
(\mathrm{cm})\end{array}$} \\
\hline & \multicolumn{8}{|c|}{ Bacteria absent or present } \\
\hline & - & + & - & + & - & + & - & + \\
\hline $\begin{array}{l}\text { Chrysanthemum } \times \text { grandiflorum } \\
\text { 'Ludo'/ Paenibacillus glucanolyti- } \\
\text { cus }(\mathrm{I})\end{array}$ & $4.6 \mathrm{a}$ & $6.1 b$ & $10.0 \mathrm{a}$ & $18.4 \mathrm{~b}$ & $5.2 b$ & $4.0 \mathrm{a}$ & $7.5 \mathrm{a}$ & $11.4 \mathrm{~b}$ \\
\hline $\begin{array}{l}\text { Gerbera jamesonii 'Kormoran'/ } \\
\text { Methylobacterium extorquens ( } 67)\end{array}$ & $1.3 \mathrm{a}$ & $1.6 \mathrm{a}$ & $7.1 \mathrm{a}$ & $\mathbf{8 . 8 b}$ & $1.8 \mathrm{a}$ & $2.2 \mathrm{a}$ & $3.8 \mathrm{a}$ & $5.9 b$ \\
\hline $\begin{array}{l}\text { Hosta 'Paradigm'/ } \\
\text { Methylobacterium extorquens ( } 67)\end{array}$ & $1.2 \mathrm{a}$ & $1.0 \mathrm{a}$ & $7.5 \mathrm{a}$ & $8.0 \mathrm{a}$ & $6.5 \mathrm{a}$ & $7.0 \mathrm{a}$ & $12.0 \mathrm{~b}$ & $7.5 \mathrm{a}$ \\
\hline $\begin{array}{l}\text { Rose 'White Gem'/ } \\
\text { Curtobacterium pusillum }(\mathrm{N})\end{array}$ & $1.4 \mathrm{a}$ & $1.9 b$ & $6.4 \mathrm{a}$ & $\mathbf{8 . 8 b}$ & $3.0 \mathrm{a}$ & $5.8 b$ & $1.2 \mathrm{a}$ & $1.6 b$ \\
\hline
\end{tabular}




\section{DISCUSSION}

Since the 1970s, it has been known that bacteria that survive the surface decontamination within the plant body and reproduce at a moderate rate, often being covert, and not causing a clear negative impact on the explants (Leifert et al. 1991; Cassels 1997, 2011), can inhabit the in vitro plant cultures. As early as in 1994, Holland and Polacco suggested that covert contaminants could be responsible for modifications of plant explants' behavior in vitro. The observation on beneficial effects of different bacteria strains on the explants in vitro raised the idea of bacterization (biotization) of plant cultures with useful bacteria (Nowak 1998; Nowak et al. 1998). The best-known candidate for biotization is the Burkholderia phytofirmans $\mathrm{PsJN}^{\mathrm{TM}}$ strain, formerly named Pseudomonas spp. PsJN, which does not grow on the plant medium in the absence of plant explants (Sessitsch et al. 2005). It colonizes both the surface and the internal tissues (Frommel et al. 1991; Nowak 1998), and stimulates the growth of microshoots and microroots, makes the use of water more efficient and increases the plant resistance to pathogens (Sharma \& Nowak 1998; Theocharis et al. 2012) and coldness (Fernandez et al. 2012). Another bacteria, Pseudomonas spp., F strain was reported to produce polysaccharides, which can inhibit an excessive hydration of oregano (Shetty et al. 1995), raspberry (Ueno et al. 1998) and anise (Bela et al. 1998) cultures. Methylobacterium sp. D10 and Methylophilus glucoseoxidans stimulated the production of morphogenetic callus from wheat embryos (Kalyaeva et al. 2003). The strain of Bacillus circulans allowed the induction of somatic embryogenesis from callus derived from geranium hypocotyls (Murthy et al. 1999) and Curtobacterium citreum stimulated outgrowth of axillary shoots in geranium cultures (Panicker et al. 2007). Azotobacter chroococcum strain increased the number of shoots in wheat (Andressen et al. 2009), Bacillus spp. stimulated root growth, and Sphingomonas spp. facilitated acclimatization of micropropagated strawberries in the greenhouse (Diaz et al. 2009) and Azospirillum barasilense 243 enhanced acclimatization of micropropagated fruit rootstocks (Vettori et al. 2010). The interaction between Paenibacillus P22 that is able to assimilate atmospheric nitrogen with poplar shoot explants resulted in essential changes in plant metabolism (Scherling et al. 2009). These observations are often consistent with the results of experiments on the interaction of bacteria with plants grown in the in vivo conditions (Russo et al. 2012).

Curtobacterium pusillum belonging to Microbacteriaceae was not only found in oil-brine fields (Ijah \& Ukpe 1992) but was also isolated from human clinical specimens (Funke et al. 2005). Its strain was one of endophytic bacteria isolated from leaves of rice plants (Mano et al. 2007) and leaves of soybean and corn (Dundleavy 1989). Strains of this bacterium were often isolated from air samples taken in food processing industries (Góra et al. 2009). El-Mehalawy (2007) selected $C$. pusillum strain producing inhibitory compounds against plant pathogen Rhizoctonia solani. Moraes et al. (2012) isolated an endophytic symbiont, the strain of $C . p u-$ sillum, which was classified as plant growth promoting bacteria (PGPB) due to the production of IAA. $C$. citreum could replace cytokinin in the medium for propagation of chrysanthemum (Panicker et al. 2007).

Methylobacteria are microorganisms commonly found in soil and on plant surfaces, but they also exist as endophytes. Many beneficial interactions of this group of bacteria with plants were detected (Madhaiyan et al. 2011). M. extorquens, which produces a pink pigment, belongs to one of the most characterized and studied methylotrophs (Christoserdova et al. 2003). Pirtilä et al. (2000) obtained the strain of this bacterium from meristematic cells of Pinus silvestris. When this strain was inoculated on the callus of that plant, it influenced the growth and regeneration by diverse mining (Pirtilä et al. 2008). The cell-free supernatant of the bacterial culture of one of M. extorquens strains isolated from strawberry promoted the growth of various seedlings (Abanda-Nkpwatt et al. 2006).

Paenibacillus genus differs in nutritional requirements and growth conditions. Many strains were isolated from soil, water, rhizosphere, plant body and food (Lorentz et al. 2006), and from in vitro cultures (Ulrich et al. 2008). Bacteria of this 
systematic group are known to secrete several enzymes and metabolites to the environment, including growth regulators (Timmusk et al. 1999). P. glucanolyticus was isolated from soil, but in our research bacteria isolated from hosta propagated in vitro was used. Sangeeth et al. (2012) found that the strain $P$. glucanolyticus isolated from the root zone of black pepper is capable of solubilizing potash, which may be important in fertilization of plants with potassium. In addition, the antimicrobial activity of several Paenibacillus strains belonging to different species was reported (Lorentz et al. 2006).

All strains of bacteria studied here were able to stably colonize in vitro explants of all four plant species but their impact on plant hosts differed. The results showed the significant influences of bacterization of microshoots of chrysanthemum, gerbera, rose and hosta using bacterial strains $-C$. pusillum, $M$. extorquens and $P$. glucanolyticus - isolated from the in vitro cultures. The character of influence depended on the host and type of organogenesis.

C. pusillum stimulated axillary shoot growth of all species and was especially effective for rose. Chrysanthemum was the only plant species which rooted worse with this bacterium. M. extorquens was especially helpful for the rooting and shoot multiplication of gerbera and hosta. It increased the number of shoots of chrysanthemum, but decreased shoot length of chrysanthemum and rose. P. glucanolyticus positively stimulated chrysanthemum for both shoot multiplication and rooting. It decreased rooting and shooting of gerbera and hosta and retarded root elongation of rose. The stimulation of shoot proliferation of all four-plant species by $C$. pusillum strain may be related to its modification of the balance of growth regulators. This strain does not produce IAA and production of any other growth regulator was not evaluated. All studied bacteria were able to assimilate atmospheric nitrogen but this fact cannot explain their specialization for different hosts.

The observed effects were not a breakthrough in micropropagation of the investigated genotypes because they are relatively easy to micropropagate without bacterial stimulation. With our experiments, we can confirm that the strains isolated from one species could colonize and be beneficial for others, hopefully also for recalcitrant genotypes, but it needs to be proved experimentally.

According to Penrose and Glick (2003), the impact of endophytes on plants is small or insignificant when they grow under optimal conditions and in fertile soil. Bacterization of plants cultivated in poor soils results in a greater stimulation of growth (Glick et al. 1998). Consequently, the influence of the bacteria on in vitro explants may not be important because in most cases cultures are grown under optimal conditions in terms of nutrition, temperature and water abundance. On the other hand, it is known that bacteria can produce all plant hormones and their facilitation can harmonize and optimize hormonal balance of plant explants (Friesen et al. 2011). Beneficial effects of bacteria may appear clearly under stress, which in micropropagation culminates during the acclimatization in the greenhouse when microplants have to develop mature covering and conducting tissues to protect plants from losing water, microbial attack, ensure the absorption and conduction of water and nutrients, and to develop the autotrophy (Chandra et al. 2010). Improving acclimatization is probably the most promising application of beneficial bacteria in the in vitro propagation industry. Digat et al. (1987), who inoculated the synthetic substrate MILCAP with strains of $P$. putida and $P$. fluorescens, suggested for the first time a need of bacterization of in vitro cultures at microshoots rooting. In their experiment, the inoculation was beneficial to some extent for Primula obconica but not for Rosa and Hydrangea quercifolia. The fully beneficial effect of bacterization of Robinia pseudoacacia with Rhizobium strains was observed by Balla et al. (1998), and Photinia fraseri with Azospirillum brasiliense by Larraburu et al. (2007). Zakharchenko et al. (2010) reported better growth of potato and strawberry at acclimatization, when microshoots were inoculated before rooting with strain of Pseudomonas aureofaciens. A strain of Azospirillum brasilense enhanced rooting and acclimatization of Prunus cerasifera (Russo et al. 2008). According to Thomas et al. (2010), bacterization of explants in vitro can be unsuccessful due to lack of colonization or culture overgrowth. In many cases, better results in plantlet survival and 
growth can be obtained when bioinoculants are used to amend the soil or during an in vitro rooting in the perlite, as in our experiment. Moreover, our experiments indicate a kind of bacteria/host specialization. Only $C$. pusillum affected all four species in the same way, but $M$. extorquens had a positive effect only on hosta and gerbera, and P. glucanolyticus only on chrysanthemum. In comparison, Burkholderia phytophirmans PsJNTM seems to have an exceptional genotype, because of its wide range of host plants (Sessitsch et al. 2005).

\section{Acknowledgement}

The authors are grateful to Lucyna Ogórek for excellent technical help.

\section{REFERENCES}

Abanda-Nkpwatt D., Musch M., Tschiersch J., Boettner M., Schwab W. 2006. Molecular interaction between Methylobacterium extorquens and seedlings: growth promotion, methanol consumption, and localization of the methanol emission site. J. Exp. Bot. 57: 4025-4032. DOI: 10.1093/jxb/erl173.

Almeida C.V., Andreote F.D., Yara R., Tanaka F.A.O., Azevedo J.L., Almeida M. 2009. Bacteriosomes in axenic plants: endophytes as stable endosymbionts. World J. Microbiol. Biotechnol. 25: 1757-1764. DOI: $10.1007 / \mathrm{s} 1274-009-0073-8$.

Andressen D., Manoochehri I., Carletti S., Llorente B., Tacoronte M., Vielma M. 2009. Optimization of the in vitro proliferation of jojoba (Simmondsia chinensis (Link) Schn.) by using rotable central composite design and inoculation with rhizobacteria. Bioagro 21: 41-48.

Balla I., Vértesy J., Köves-Péchy K., Vörös I., Bujtás Z., Bíró B. 1998. Acclimation results of micropropagated black locust (Robinia pseudoacacia L.) improved by symbiotic micro-organisms. Plant Cell Tiss. Org. 52: 113-115. DOI: 10.1023/A:1005974024515.

Beattie G.A. 2006. Plant-associated bacteria: survey, molecular phylogeny, genomics and recent advances. In: Gnanamanickam S.S. (Ed.), Plant-Associated bacteria. Springer, Dordrecht, The Netherlands, pp. $1-56$.

Bela J., Ueno K., Shetty K. 1998. Control of hyperhydricity in anise (Pimpinella anisum) tissue culture by Pseudomonas spp. J. Herbs Spices Med. Plants 6: 57-67. DOI: 10.1300/J044v06n01_08.
Cassels A.C. 1997. Pathogen and microbial contamination management in micropropagation - an overview. In: Cassels A.C. (Ed.), Pathogen and Microbial Contamination Management in Micropropagation. Kluwer Academic Publishers, Dordrecht, pp. 1-13.

Cassels A.C. 2011. Detection and elimination of microbial endophytes and prevention of contamination in plant tissue culture. In: Trigiano R.N. and Gray D.J (Eds.), Plant Tissue Culture, Development, and Biotechnology, CRC Press, Taylor \& Francis Group, Boca Raton, pp. 223-238.

Chandra S., Bandopadhyay R., Kumar V., Chandra R. 2010. Acclimatization of tissue cultured plantlets: from laboratory to land. Biotechnol. Lett. 32: 11991205. DOI: 10.1007/s10529-010-0290-0.

Christoserdova L., Chen S.-W., Lapidus A., Lindstrom M.E. 2003. Methylotrophy in Methylobacterium extorquens AM1 from a genomic point of view. J. Bacteriol. 185: 2980-2987. DOI: 10.1128/JB.185.10.2980-2987.2003.

Compant S., Duffy B., Nowak J., Clement C., Ait Barka E. 2005. Use of plant growth-prompting bacteria for biocontrol of plant diseases: principles, mechanisms of action, and future prospects. Appl. Environ. Microb. 71: 4951-4959. DOI: 10.1128/AEM.71.9.4951-4959.2005.

Diaz A.C.F., Costa F.E.C., Andreote F.D., Lavaca P.T., Teixeira M.A., Assumpção L.C., Araújo W.L., Azevedo J.L., Melo I.S. 2009. Isolation of micropropagated strawberry endophytic bacteria and assessment of their potential for plant growth promotion. World J. Microb. Biot. 25: 189-195. DOI: 10.1007/s11274-008-9878-0.

Digat B., Brochard P., Hermelin V., Touzet M. 1987. Interest of bacterized synthetics substrates MILCAP ${ }^{\circledR}$ for in vitro culture. Acta Hort. 212: 375-378.

Dundleavy J.M. 1989. Curtobacterium plantarum sp. nov. is ubiquitous in plant leaves and is seed transmitted in soybean and corn. Int. J. Syst. Bacteriol. 39: 240-249. DOI: 10.1099/00207713-39-3-240.

El-Mehalawy A.A. 2007. Effect of antifungal agents on the physiological activities of towo plant pathogenic fungi: Rhizoctonia solani \& Fusarium oxysporum. Egyptian J. Biotechnol. 25: 159-168. http://dx.doi.org/10.4314/ejbiot.v25i1.40284

Fernandez O., Theocharis A., Bordiec S., Feil R., Jacquens L., Clement C., Fontaine F., Ait Barka E. 2012. Burkholderia phytofirmans PsJN acclimates grapevine to cold by modulating carbohydrate metabolism. Mol. Plant-Microbe In. 25: 496-504. DOI: 10.1094/MPMI-09-11-0245. 
Friesen M.L., Porter S.S., Stark S.C., von Wetteberg E.J., Sachs J.L., Martinez-Romero E. 2011. Microbially mediated plant functional traits. Annu. Rev. Ecol. Evol. S. 42: 23-46.

Frommel M.I., Novak J., Lazarovits G. 1991. Growth enhancement and developmental modifications of in vitro grown potato (Solanum tuberosum ssp. tuberosum) as affected by a nonfluorescent Pseudomonas sp. Plant Physiol. 96: 928-936.

Funke G., Aravena-Roman M., Frodl R. 2005. First description of Curtobacterium spp. isolated from human clinical specimens. J. Clin. Microbiol. 43: 1032-1036. DOI: 10.1128/JCM.43.3.10321036.2005.

Glickmann E., Dessaux Y. 1995. A critical examination of the specificity of the Salkowski reagent for indolic compounds produced by phytopathogenic bacteria. Appl. Environ. Microb. 61(2): 793-796.

Glick B.R., Penrose D.M., Li J. 1998. A model for the lowering of plant ethylene concentrations by plant growth-promoting bacteria. J. Theor. Biol. 190: $63-$ 68.

Góra A., Mackiewicz B., Krawczyk P., Golec M., Skórska C., Sitkowska J., Cholewa G., Larsson L., Jarosz M., Wójcik-Fatla A., Dutkiewicz J. 2009. Occupational exposure to organic dust, microorganisms, endotoxin and peptidoglycan among plants processing workers in Poland. Ann. Agric. Environ. Med. 16: 143-150.

Hardoim P.R., van Overbeek L.S., van Elsas J.D. 2008. Properties of bacterial endophytes and their proposed role in plant growth. Trends in Microbiology, 16: 463-471. DOI: 10.1016/j.tim.2008.07.008.

Holland M.A., Polacco J.C. 1994. PPFMs and other covert contaminants: is there more to plant physiology than just plant? Annu. Rev. Plant Physiol. Plant Mol. Biol. 45: 197-209. DOI: 10.1146/annurev.pp.45.060194.001213.

Ijah U.J.J., Ukpe L.I. 1992. Biodegradation of crude oil by Bacillus strains 228A and 61B isolated from oil spilled soil. Waste Manage 12: 55-60.

Kalyaeva M.A., Ivanova E.G., Doronina N.V., Zakharchenko N.S., Trotsenko Y.A., Buryanov Y.I. 2003. The effect of aerobic methylotrophic bacteria on the in vitro morphogenesis of soft wheat (Triticum aestivum). Rus. J. Plant Physiol. 50: 313317.

Larraburu E.E., Carletti S.M., Cáceres E.A.R., Llorente B.E. 2007. Micropropagation of photinia employing rhizobacteria to promote root development.
Plant Cell Reports 26: 711-717. DOI: 10.1007/s00299-006-0279-2.

Leifert C., Ritchie J.Y., Waites W.M. 1991. Contaminants of plant tissue and cell cultures. World J. Microbiol. Biotechnol. 7: 452-469. DOI: http://dx.doi.org/10.1007/BF00303371

Lloyd G., McCown B. 1981. Commercially feasible micropropagation of Mountain Laurel, Kalmia latifolia, by use of shoot tip culture. International Plant Propagators' Society 30: 421-427.

Lorentz R.H., Artico S., da Silveira A.B., Einsfeld A., Corçäo G. 2006. Evaluation of antimicrobial activity in Paenibacillus spp. strains isolated from natural environment. Let. Appl. Microbiol. 43: 541547. DOI: 10.1111/j.1472-765X.2006.01995.x.

Madhaiyan M., Chauhan P.S., Yim W.J., Boruah H.P.D., Sa T.M. 2011. Diversity and beneficial interactions among Methylobacterium and plants. In: Maheshwari D.K. (Ed.), Bacteria in Agrobiology: Plant growth responses. Springer-Verlag Berlin, Heidelberg: 259-284. DOI: 10.1007/978-3-64220332-9.

Mano H., Tanaka F., Nakamura C., Kaga H., Morisaki H. 2007. Culturable endophytic bacterial flora of the matu ring leaves and roots of rice plants (Oryza sativa) cultivaterd in paddy field. Microbes Environ. 22: 175-185. http://wwwsoc.nii.ac.jp/jsme2/

Moraes R.M., Melo I.S., Samyanto J., Chandra S., Joshi V. 2012. Bacterial community associated with autotrophic and heterotrophic cultures of medicinal plant Smallanthus sonchifolius (Yacon). Am. J. Plant Sci. 3: 1382-1389. DOI:10.4236/ajps.2012.310167.

Murashige T., Skoog F. 1962. A revised medium for rapid growth and bio-assays with tobacco tissue culture. Physiol. Plant. 15: 473-497. DOI: 10.1111/j.13993054.1962.tb08052.x.

Murthy B.N.S., Vettakkorumakankav N.N., KrishnaRaj S., Odumeru J., Saxena P.K. 1999. Characterization of somatic embryogenesis in Pelargonium $\times$ hortorum mediated by a bacterium. Plant Cell Reports 18: 607-613. DOI: 10.1007/s002990050630.

Nowak J. 1998. Review. Benefits of in vitro "biotization" of plant tissue cultures with microbial inoculants. In Vitro Cell. Dev.-Pl. 34: 122-130.

Nowak J., Asiedu S.K., Bensalim S., Richards J., Stewart A., Smith C., Stevens D., Sturz A.V. 1998. From laboratory to applications: challenges and progress with in vitro dual cultures of potato and beneficial bacteria. Plant Cell Tiss. Org. 52: 97-103. DOI: 10.1007/978-94-015-8951-2_39. 
Ortiz-Castro R., Contreras-Cornejo H.A., Macias-Rodriguez L., Lopez-Bucio J. 2009. The role of microbial signals in plant growth and development. Plant Signaling Behav. 4: 701-712. DOI: 10.4161/psb.4.8.9047.

Panhwar Q.A., Radziah O., Sariah M., Mohd Razi I. 2009. Solubilization of phosphate forms by solubilizing bacteria isolated from aerobic rice. Int. J. Agric. Biol. 11: 667-673.

Panicker B., Thomas P., Janakiram T., Venugopalan R., Narayanappa S.B. 2007. Influence of cytokinin levels on in vitro propagation of shy suckering chrysanthemum 'Arka Swarna' and activation of endophytic bacteria. In Vitro Cell. Dev.-Pl. 43: 614-622. DOI: $10.1007 / \mathrm{s} 11627-007-9061-6$.

Penrose D.M., Glick B.R. 2003. Methods for isolating and characterizing ACC deaminase-containing plant growth-promoting rhizobacteria. Physiol. Plant 118: 10-15. DOI: 10.1034/j.13993054.2003.00086.x.

Pirtilä A.M., Laukkanen H., Pospieh H., Myllylä R., Hohtola A. 2000. Detection of intracellular bacteria in the buds of Scotch pine (Pinus silvestris L.) by in situ hybridization. Appl. Environ. Microbiol. 66: 3073-3077. DOI: 10.1128/AEM.66.7.30733077.2000.

Pirtilä A.M., Podolich O., Koskimäki J.J., Hohtola E., Hohtola A. 2008. Role of origin and endophyte infection in browning of bud-derived tissue cultures of Scots pine (Pinus sylvestris L.). Plant Cell Tiss. Org. 95: 47-55. DOI: 10.1007/s11240-008-9413-x.

Ribeiro C.M., Cardoso E.J.B.N. 2012. Isolation, selection and characterization of root-associated growth promoting bacteria in Brazil Pine (Araucaria angustifolia). Microbiol. Res. 167: 69-78. DOI: 10.1016/j.micres.2011.03.003.

Russo A., Carozza G.P., Vettori L., Felici C., Cinelli F., Toffanin A. 2012. Plant beneficial microbes and their application in plant biotechnology. In: Agbo E.C. (Ed.), Innovations in Biotechnology. Kindle Edition, Rijeka, Croatia, pp. 57-72. DOI: $10.5772 / 31466$.

Russo A., Vettori L., Felici C., Fiaschi G., Morini S., Toffanin A. 2008. Enhanced micropropagation response and biocontrol effect of Azospirillum brasiliense Sp245 on Prunus cerasifera L. clone Mr.S 2/5 plants. J. Biotechnol. 134: 312-319. DOI: 10.1016/j.jbiotec.2008.01.020.

Ryan R.P., Germaine K., Franks A., Ryan D.J., Dowling D.M. 2008. Bacterial endophytes: recent developments and applications. FEMS Microbiol. Lett. 278: 1-9. DOI: 10.1111/j.1574-6968.2007.00918.x.
Sangeeth K.P., Suseela Bhai R., Srinivasan V. 2012. Paenibacillus glucanolyticus, a promising potassium solubilizing bacterium isolated from black pepper (Piper nigrum L.) rhizosphere. J. Spices Arom. Crops 21: 118-124.

Scherling C., Ulrich K., Ewald D., Weckewerth W. 2009. A metabolic signature of the beneficial interaction of the endophyte Paenibacillus sp. isolate and in vitro-grown poplar plants revealed by metabolomics. Mol. Plant-Microbe In. 22: 1032-1037. DOI: 10.1094/MPMI-22-8-1032.

Sessitsch A., Coenye T., Sturz A.V., Vandamme P., Ait Barka E., Salles J.F., Van Elsas J.D., Faure D., Reiter B., Glick B.R., Wang-Pruski G., Nowak J. 2005. Burkholderia phytofirmans sp. nov., a novel plant-associated bacterium with plant-beneficial properties. Int. J. Syst. Evol. Micr. 55: 1187-1192. DOI: 10.1099/ijs.0.63149-0.

Sharma V.K., Nowak J. 1998. Enhancement of verticillium wilt resistance in tomato transplants by in vitro co-culture of seedlings with a plant growth promoting rhizobacterium (Pseudomonas sp., strain PsJN). Can J. Microbiol. 44: 528-536. DOI: 10.1139/w98-017.

Shetty K., Curtis O.F., Levin R.E., Witkowsky R., Ang W. 1995. Prevention of vitrification associated with in vitro shoot culture of oregano (Origanum vulgare) by Pseudomonas spp. J. Plant Physiol. 147: 447-451. DOI: 10.1016/S0176-1617(11)82181-4.

Sziderics A.H., Rasche F., Trognitz F., Sessitsch A., Wilhelm E. 2007. Bacterial endophytes contribute to abiotic stress adaptation in pepper plants (Capsicum annuиm L.). Can. J. Microbiol. 53: 1195-1202. DOI: 10.1139/W07-082.

Theocharis A., Bordiec S., Fernandez O., Paquis S., Dhondt-Cordelier S., Bailieul F., Clement C., Ait Barka E. 2012. Burkholderia phytofirmans PsJN primes Vitis vinifera L. and confers a better tolerance to low nonfreezing temperatures. Mol. PlantMicrobe In. 25: 241-249. DOI: 10.1094/MPMI-0511-0124.

Thomas J., Ajay D., Raj Kumar R., Mandal A.K.A. 2010. Influence of beneficial microorganisms during in vivo acclimatization of in vitro-derived tea (Camellia sinensis) plants. Plant Cell Tiss. Org. 101: 365370. DOI: 10.1139/W06-141.

Timmusk S., Nicander B., Granhall U., Tillberg E. 1999. Cytokinin production by Paenibacillus polymyxa. Soil Biol. Biochem. 31: 1847-1852. DOI: 10.1016/S0038-0717(99)00113-3. 
Ueno K., Cheplick S., Shetty K. 1998. Reduced hyperhydricity and enhanced growth of tissue culture - generated raspberry (Rubus sp.) clonal lines by Pseudomonas sp. isolated from oregano. Process Biochem. 33: 441-445. DOI: 10.1016/S00329592(98)00011-9.

Ulrich K., Stauber T., Ewald D. 2008. Paenibacillus a predominant endophytic bacterium colonizing tissue cultures of woody plants. Plant Cell Tiss. Org. 93: 347-351. DOI: 10.1007/s11240-008-9367-z.

Vettori L., Russo A., Felici C., Fiaschi G., Morini S., Toffanin A. 2010. Improving micropropagation: effect of Azospirillum brasilense Sp245 on acclimatization of rootstocks of fruit tree. J. Plant Interact. 5: 249-259. DOI: 10.1080/17429145.2010.511280.
Viss P.R., Brooks E.M., Driver J.A. 1991. A simplified method for the control of bacterial contamination in woody plant tissue culture. In Vitro Cell. Dev.-Pl. 27(1): 42. DOI: 10.1007/BF02632060.

Weisburg W.G., Barns S.M., Pellettier D.A., Lane D.J. 1991. 16S ribosomal DNA amplification for phylogenetic study. J. Bacteriol. 173: 697-703.

Zakharchenko N.S., Kochetkov V.V., Buryanov Ya.I., Boronin A.M. 2011. Effect of rhizosphere bacteria Pseudomonas aureofaciens on the resistance of micropropagated plants to phytopathogens. Appl. Biochem. Microbiol. 47: 661-666. DOI: 10.1134/S0003683811070118. 